\section{Internationalization and Relationships in Supply Chains}

\author{
Adriana Troczinski Storti ${ }^{1, \dagger}$ \\ ${ }^{1}$ IFRS (Instituto Federal de Educação, Ciência e Tecnologia do Rio Grande do Sul), Erechim, RS, Bražil \\ Ely Paiva $2, \Omega$ \\ ${ }^{2}$ FGV-EAESP, São Paulo, SP, Brazil \\ Luciana Marques Vieira ${ }^{3, \ldots}$ \\ ${ }^{3}$ FGV-EAESP, São Paulo, SP, Brazil
}

\section{ABSTRACT}

From the perspective of supply chain management a multinational may shape its "network of relationships" differently in each country in which it operates. This paper aims to analyze the supply chain relationships of a Brazilian multinational in different national contexts. We analyzed the presence and alignment of key aspects of the relationship based on the perception of those involved in the supply chains we analyzed. The method included personal interviews and lexical analysis carried out using data analysis software. The results suggest that the external environment and the strategies adopted have an effect on the types of relationship found in the supply chains analyzed. The company has different business strategies in each of its units. Business strategies that seek greater differentiation or value creation, like those of the Argentinian unit, lead to higher levels of cooperation and collaboration. At the other extreme, a greater focus on costs in the Brazilian unit results in low levels of trust, which is reflected in incipient cooperation and collaboration.

Keywords: Relationships; Supply Chain; Multinational; Food.

\section{INTRODUCTION}

Culture, communication, technology, politics, economics, innovation and the workforce may impact the activities of multinational companies in international markets. All these elements have an influence on the competitiveness of these companies (MEYER, 2004). It is also important to point out that one of the challenges a multinational faces is understanding the specifics of the context in which its subsidiary units are located, which includes among other aspects local relations, local knowledge, their capacity to absorb new knowledge and learning processes.

Brazilian companies from various industrial sectors have been expanding their international operations, and the country distinguishes itself as a global player in meat production (beef, pork and chicken). Although Brazil is the leader in beef exports, the country is seeking to be recognized as a source of quality for other markets. Within this perspective, companies in this sector are able to access markets and offer premium prices by acquiring industrial plants in different countries.

Although the issue of supply is crucial in any internationalization process, studies of Brazilian multinationals rarely address supply 
management, although it is a topic we find in some foreign studies, such as those by Houlihan (1985) and Perez-Aleman and Sandilands (2008). Studies on Brazilian multinational companies have addressed topics such as competencies (Fleury \& Fleury, 2011; Borini, 2011), innovation (Borini et al, 2012) and entry strategies (Arbix \& Caseiro, 2011). Changes in the supply chain in companies that develop internationalization activities is an important subject, though it is still a theme with few existing studies. Therefore, this study discusses the relationships between participants in supply chains following international acquisition processes. The characteristics of these relationships are presented from the viewpoint of the relationship that exists between the multinational's headquarters and its subsidiary units, and between the latter and their suppliers in the countries in which they operate.

The questions guiding this study, therefore, are: How are the relationships in the supply chain of a Brazilian multinational presented? Are there any differences between the operations in Brazilian and international contexts?

We collected data through direct observation and face-to-face interviews with managers from the parent company's headquarters in São Paulo, the unit located in the southern region of Brazil and the subsidiary companies in Uruguay and Argentina.

The text first presents theoretical references relating to the acquisition of companies and relationships in supply chains. The following sections describe the company and offer an analysis of the characteristics of the relationship between the units in Brazil, Uruguay and Argentina and their main suppliers (producers and consignees). The main conclusions of the study and new questions for advancing research into this subject are presented at the end of the paper.

\section{TheORETICAL REFERENCE}

\subsection{COMPANY ACQUISITION STRATEGY}

Hennart and Park (1993) state that when a multinational makes an acquisition, one of the challenges it faces is how to coordinate and manage the relationships involved, considering that the subsidiaries have knowledge about their own internal and external relationships and the way they function. These relationships create a challenge for the buyer, who must understand them and make them fit for the development of their own strategies.

There is often a great degree of uncertainty in international environments, which present international operations with significant challenges, and these can be minimized by improving relationships between players in the supply chain. (KLASSEN, WHYBARK, 1994). In the competitive context of international markets the execution of operations drives multinational companies towards greater involvement with local players, with the objective of becoming more effective in their activities and achieving greater global synergy (PRASAD \& BABBAR, 2000).

In studies on the formation of joint ventures, the literature presents the concept of partner cooperation as being the opposite of the concept of opportunism (PARK \& UNGSON, 2001). We can extend this approach to include the discussion about multinational companies. In this case, when those involved cooperate they avoid the opportunistic behavior of their partners and create the potential for effective gains (ARIÑO, 2003; LUO \& PARK, 2004).

Meyer and Estrin (2001) also point out to the capacity that purchasing companies have for appropriating the knowledge that the acquired organizations possess of the local market. This implies maintaining the resources and competences that are necessary for the new management model, which may or may not replicate the strategy of the parent company. The capacity the subsidiary has for absorbing new knowledge is also important, since new strategies are drawn up following completion of the acquisition process (Fang \& Zou, 2010). 
BBR

15,6

553

Resistance to change, the existing culture and the local economic situation may also have an influence on the results of any new international operation.

\subsection{RELATIONSHIP AND TRUST IN THE SUPPLY CHAIN}

Burgess, Singh and Koroglu (2006) emphasize that there are five main aspects in relationships: information sharing, their long-term nature, collaboration, logistical integration, and the sharing of risks and returns. We identify these aspects following the analysis of 43 empirical studies that were published between 1996 and 2007 in the main journals in the field of operations management.

According to Mentzer et al. (2001), relationships in supply chains can generally be analyzed from the viewpoint of the direct chain, in other words, the vertical relationships that exist between the focal company and its suppliers and distributors. When relationships involve partners of the same size they are usually more collaborative, while they tend to be more coercive when there are differences in size and bargaining power in the relationship. (Capó-Vicedo, Mula \& Capó, 2011; Huang, Yen \& Liu, 2014). Collaborative relationships involve trust, commitment, cultural aspects, and the availability of human capital for the development of this type of relationship.

The institutional and transaction cost approaches deal with trust as a rational or cognitive choice (McALLISTER, 1995). A reduction in trust, however, can generate conflicts, leading to demotivated participants and the non-development of collaborative activities (MADHOK, 1995). This author believes there is a structural component in trust that refers to the complementary nature of the resources involved. On the other hand, the social component of trust is related to the quality of the relationship, influenced by the perception of continued equity between those involved.

Trust grows over time (GAO \& BROWN, 1998) and each one involved has their own characteristics and qualities that allow them to act and trust in a unique way (HOFSTEDE $\&$ BOND, 1988). In the individual context, we find the term affective trust when there is an individual who has characteristics that are trustworthy (LINDGREEN, 2003). In organizational terms, trust between buyer and seller is defined as a conviction, an expectation or a feeling about a partner, resulting from their knowledge, reliability and intentions.

Some authors analyze the role of trust in relationships between companies from a sociological perspective. They point out that there are at least two parties/parts involved: those who trust and the basis for that trust, which may be a company, an institution or a product (Zucker, 1986, VIEIRA \& TRAILL, 2008). For Dyer and Chu (2011), when the lack of trust is due to specific aspects of the partner's regional context, the company should identify other mechanisms aimed at compensating for this gap, such as monitoring and risk control systems.

By adopting a broader focus, market demands put pressure on companies' ability to respond, which justifies the search for cooperative activities in supply chains (SIMATUPANG $\&$ SRIDHARAN, 2002). Cantwell, Dunning and Lundan (2010) also stress the importance of the environment in existing relationships. For these authors, internal and external variables, such as political, economic and social aspects, can influence businesses' strategy, learning and innovation, which tends to act in a cooperative way according to the context.

For Wilding and Humphries (2006), co-operation, coordination, and collaboration are important for reducing opportunistic behavior in relationships. According to studies by Whipple and Russel (2007), there are various types of cooperation, it is up to managers to understand and adapt these types according to their own particular business and reality. The environment is more complex for multinational companies because of the multiplicity of variables involved. At the same time, simple actions that do not require large financial investments can often strengthen cooperation between companies (SINGH \& POWER, 
2009). Because of the different forms of cooperation and collaboration that exist, McDuffie (2011) suggests that there are different types of trust in relationships, including: collaborative trust, which is linked to the reputation, competence and involvement of individuals; traditional trust, which is found in existing social relations; charismatic trust, which is linked to positive personal characteristics; and contractual trust, which is based on systems and institutions that reinforce expectations of reliability.

\subsection{AlignMent IN THE SUPPLY CHAIN}

In order to achieve common organizational goals organizations need to involve different players. In the literature, this is termed as alignment and can occur at both the strategic and information levels, especially in more comprehensive relationships, such as in a supply chain (CHEN \& PAULRAJ, 2004).

The discussion about alignment also focuses on the relationship between buyer and supplier. Wu and Cavusgil (2005) understand that for many organizations it is important to develop a "relationship map", which in a broader perspective helps align commercial relations. This alignment is drawing together information in the search for consensus between those involved. Even in situations in which relationships align, we cannot assure the absence of conflicts. This may also occur because of the limited rationality of the participants and the presence of opportunistic behavior. Juttner, Godsell, and Christopher (2006) cite the importance of alignment along the whole chain, which comprises everything from production to demand, with the objective being of delivering products to market that efficiently create value for the customer.

For Paiva, Carvalho Jr. and Fensterseifer (2009), a supply chain strategy should ideally generate gains for all those involved. In this sense, relationships between buyer and supplier become a strategic issue, since the success of a company may be related to the strategy it adopts for managing its suppliers. The authors also emphasized that in order to understand the influence of the strategic positioning of the company on the performance of the supply chain, the following are relevant: the level of the relationship with suppliers; the level of the supplier's involvement with product development; the supplier's selection criteria; and how the size of the supplier base is established.

In addition to the importance of observing the alignment that exists between members in the supply chain, what we need to understand is the alignment that exists between subsidiary units and the parent company, since the former may sometimes become dependent on corporate resources, such as capital, technology and knowledge (CRILLY, 2011). When a multinational company increases its knowledge of the production and commercial activities of its subsidiary, it will possibly seek to promote greater information exchange between those involved. Therefore, these actions will help increase alignment between the parties.

\section{Methodological Procedures}

We chose the case study research method. Voss, Tsikriktsis and Frohlich (2002) state that case studies are capable of understanding and analyzing non-standard behaviors. Barrat, Choi and Li (2011) complement by arguing that case studies can play the role of testing existing theory and are not just for constructing new theories.

We analyze the case of a Brazilian multinational company with subsidiary units in Brazil, Argentina and Uruguay. We chose this particular company because it is considered as a Brazilian multinational (KPMG, 2010), which operates in the food sector, a segment which was estimated to grow in subsequent years (USDA, 2011), and which has a strong presence in countries in South America (Brazil, Argentina and Uruguay).

We conduct the pre-arranged interviews in the respondents' work environment and in the country's official language. We interviewed managers from Brazilian, Uruguayan and 
BBR

15,6

Argentinian units, and suppliers (producers and consignees) from all three countries. We first transcribed the interviews by writing them out by hand and then inputting for future analyses using the Sphinx Brazil program.

Any potential Spanish language barrier was mitigated by the researchers' own knowledge of this language. Table 1 below details the profile and purpose of each collection

Table 1. Data collection sources and the collection objectives in each unit studied

\begin{tabular}{|c|c|c|c|}
\hline Position/Contact & Form & Unit & Objective \\
\hline HR Supervisor & Personal interview & Brazil & $\begin{array}{l}\text { Authorization for car- } \\
\text { rying out the study in the } \\
\text { Brazilian unit }\end{array}$ \\
\hline $\begin{array}{l}\text { Cattle Procurement Ma- } \\
\text { nager }\end{array}$ & Personal interview & Brazil & $\begin{array}{l}\text { To identify how chain } \\
\text { relationships occur in } \\
\text { the opinion of the in- } \\
\text { dustry }\end{array}$ \\
\hline Producers (2) & Personal interview & Brazil & $\begin{array}{l}\text { To identify how chain } \\
\text { relationships occur in } \\
\text { the opinion of the pro- } \\
\text { ducers }\end{array}$ \\
\hline Consignees (2) & Personal interview & Brazil & $\begin{array}{l}\text { To identify how chain } \\
\text { relationships occur in } \\
\text { the opinion of the in- } \\
\text { dustry }\end{array}$ \\
\hline $\begin{array}{l}\text { Operations level em- } \\
\text { ployees }\end{array}$ & $\begin{array}{l}\text { Observation in the HR } \\
\text { sector }\end{array}$ & Brazil & $\begin{array}{l}\text { To get to know the } \\
\text { company's industrial } \\
\text { processes }\end{array}$ \\
\hline $\begin{array}{l}\text { Legal Sector in the hea- } \\
\text { dquarters in SP }\end{array}$ & Telephone & Brazil & $\begin{array}{l}\text { To seek authorization for } \\
\text { the study }\end{array}$ \\
\hline Administrative Assistant & Telephone and e-mail & Uruguay & To arrange visits \\
\hline Administrative Director & $\begin{array}{l}\text { Personal interview Ob- } \\
\text { servation }\end{array}$ & Uruguay & $\begin{array}{l}\text { To identify how chain } \\
\text { relationships occur in } \\
\text { the opinion of the in- } \\
\text { dustry }\end{array}$ \\
\hline HR Director & $\begin{array}{l}\text { Personal interview Ob- } \\
\text { servation }\end{array}$ & Uruguay & $\begin{array}{l}\text { To collect general infor- } \\
\text { mation about the unit }\end{array}$ \\
\hline Farm Sector & $\begin{array}{l}\text { Personal interview Ob- } \\
\text { servation }\end{array}$ & Uruguay & $\begin{array}{l}\text { To seek information } \\
\text { about relationships with } \\
\text { producers }\end{array}$ \\
\hline Production Manager & $\begin{array}{l}\text { Personal interview Ob- } \\
\text { servation }\end{array}$ & Uruguay & $\begin{array}{l}\text { To get to know the unit } \\
\text { and its industrialization } \\
\text { processes }\end{array}$ \\
\hline Producers (2) & Personal interview & Uruguay & $\begin{array}{l}\text { To seek information } \\
\text { about chain relationships }\end{array}$ \\
\hline Consignees (2) & Personal interview & Uruguay & $\begin{array}{l}\text { To seek information } \\
\text { about relationships with } \\
\text { the industry }\end{array}$ \\
\hline $\begin{array}{l}\text { Tacuarembó Adminis- } \\
\text { tration }\end{array}$ & $\begin{array}{l}\text { Personal interview and } \\
\text { e-mail }\end{array}$ & Uruguay & $\begin{array}{l}\text { To seek information } \\
\text { about the industry and } \\
\text { how representative it is } \\
\text { for the municipality }\end{array}$ \\
\hline
\end{tabular}




\begin{tabular}{|c|c|c|c|}
\hline Unit General Manager & E-mail & Uruguay & To arrange visits \\
\hline Administrative Director & $\begin{array}{l}\text { Personal interview } \mathrm{Ob} \text { - } \\
\text { servation }\end{array}$ & Argentina & $\begin{array}{l}\text { To seek to identify the } \\
\text { company's view of chain } \\
\text { relationships and what } \\
\text { the relationship with } \\
\text { producers and interme- } \\
\text { diaries is like }\end{array}$ \\
\hline Producers (2) & Telephone and e-mail & Argentina & $\begin{array}{l}\text { To seek to identify what } \\
\text { chain relationships are } \\
\text { like }\end{array}$ \\
\hline Consignees (1) & E-mail & Argentina & $\begin{array}{l}\text { To seek to identify what } \\
\text { chain relationships are } \\
\text { like }\end{array}$ \\
\hline Sheep farm (1) & E-mail & Argentina & $\begin{array}{l}\text { To seek to identify what } \\
\text { the relationship with the } \\
\text { industry is like }\end{array}$ \\
\hline $\begin{array}{l}\text { Meat Producers Asso- } \\
\text { ciation }\end{array}$ & E-mail & Argentina & $\begin{array}{l}\text { To understand the Ar- } \\
\text { gentinian meat industry }\end{array}$ \\
\hline $\begin{array}{l}\text { ApexBrasil, IPCVA and } \\
\text { INTI }\end{array}$ & E-mail & Argentina & $\begin{array}{l}\text { To understand the Ar- } \\
\text { gentinian meat industry }\end{array}$ \\
\hline
\end{tabular}

Source: Authors' own elaboration

exercise, emphasizing that in cases where we contacted more than one participant per segment, we also show the number of participants in the first column.

Following the data collection, we coded and then analyzed them on the basis of this coding. Data analysis used elements of narrative analysis. Webster and Mertova (2000) define narrative as a series of human stories related to experiences. This study fits what Riessman (2007) called thematic analysis. Even if narrative analysis initially chose to address the informal or more spontaneous situations of the players involved, over time semi-structured interviews became an accepted way of collecting and analyzing data (Mishler, 1986). The emphasis in this case is more on the content of the text. Thus, we focus more on "what" was said rather than on "how" it was narrated. The analytical coding of 'presence' is based on concepts, which for Gibbs (2009), are the analysis categories taken from the literature review. The analysis categories resulting from the theory were: Trust, Coordination, Communication, Cooperation and Involvement. We structured this coding on levels (low, medium or high), based on the description of the information provided by the interviewees, the verbal force of the comments they made, the lack of answers for the questions and, in some cases, the presence of doubt in the respondents' comments. Words and phrases such as "No", "There aren't any", "It doesn't exist", and "Only by them" indicated a low level of presence. On the other hand, words such as "Can improve", "A little", and "Not always" indicated a medium level, while the words "Yes" "There is", "It exists" and "Good" were considered to be a high level.

We based the analytical coding of the alignment on data. This means that we can identify situations that are: non-existent, when there is a total misalignment in the presence indicators of the analysis categories commented upon by the participants; low alignment; medium alignment; and high alignment, when an answer is close to the analysis categories by type of relationship in each of the units studied.

The application of lexical and content analysis in this research allowed us to identify expressions and words that obtained a number of citations equal to, or greater than three for each category studied. It is also worth noting that in the interviews, some of the testimonies denied the existence of cooperation and involvement. This information is presented in Table 2. 
BBR

15,6

Table 2. Greatest incidence of expressions cited by the participants

\begin{tabular}{|c|c|}
\hline Criterion & Expressions cited and number of citations \\
\hline Trust & $\begin{array}{l}\text { There is autonomy (8); There isn't any (7); There is } \\
\text { no access to the headquarters (6); There is trust (5); } \\
\text { There is none (5); There are no contracts (3); }\end{array}$ \\
\hline Cooperation & $\begin{array}{l}\text { There is none (11); There is cooperation (10); Con- } \\
\text { tact with the headquarters (3); Geographical distan- } \\
\text { ce (3); There's competition (3); There is no access } \\
\text { (3); It could improve (3) }\end{array}$ \\
\hline Communication & $\begin{array}{c}\text { There is none (8); There is no access (4); There's no } \\
\text { contact (4); There's no access to the headquarters } \\
\text { (3); There's no contact with the headquarters (3); } \\
\text { They are discussed (3) }\end{array}$ \\
\hline Involvement & $\begin{array}{c}\text { There is none (10); The industry defines it (3); } \\
\text { Access to the headquarters (3); There's not much } \\
\text { access (3) }\end{array}$ \\
\hline Coordination & $\begin{array}{c}\text { There isn't any (6); It could improve (5); Access to } \\
\text { the headquarters (3); There's not much access ( } 3 \text { ); } \\
\text { There always is (3) }\end{array}$ \\
\hline
\end{tabular}

Source: Authors' own elaboration

\section{The Headquarters and its Relationships With the Produc- TION UNITS}

The company we studied has been active in the processing and distribution of beef, sheep, pork and poultry products since 1986 . At the time of the research, it had units in 22 countries on five continents, with 150 manufacturing plants, sales representation offices and distribution centers. It is considered to be one of the most internationalized and diversified Brazilian companies in the food sector. For its expansion into domestic and international markets, it used a strategy of unit acquisition.

The company has a low cost strategy for the Brazilian unit, with low levels of financial investment and little integration effort. The international units in Uruguay and Argentina, on the other hand, are located in markets where the goal is to add value to the products. Based on their business strategies, therefore, these units' actions may focus more on cooperation and collaboration.

We identified structural and social trust in the three units we analyzed, in accordance with the comments listed in the text. The comments are identified by interviewee and involve the company's management ( $\mathrm{I}$ - the industry), producers $(\mathrm{P})$ and consignees $(\mathrm{C})$. In the case of structural trust, resources play a key role as does achieving goals.

"Formal commitment by the producers is an element of our standardization and safety, which are necessary in certification programs." (I - Brazil)

"The consignee is responsible and assumes a commitment to the producer's cattle vis-à-vis in the industry, without documents or bureaucratic processes. " (C - Uruguay)

"Producers realize that we have a lot to offer in structural terms." (I - Argentina)

Social trust, which comes from collaboration between the people involved, is also present. We can identify this second type of trust both, in the words of company management (I) and consignees $(\mathrm{C})$ :

“The company's word is strong." (C - Brazil) 
"Its word is its commitment." (I - Brazil)

"We always help each other." (P - Argentina)

Although previous studies state that trust and cooperation are always associated, there is no complete agreement on this position (WITT \& LEWIN, 2007). Other institutional aspects, such as national legal authorizations, led to cooperation in the case of the company. So the institutional environment favors the perception of trust:

"Formal commitment by the producers is an element of our standardization and safety, which is necessary in certification programs. " (I - Uruguay)

As for cooperation, the parties involved also recognize this, although the perception varies. This aspect can be identified in the inhomogeneous discourse that exists between those involved in the company's supply chain.

"An effort is made to cascade down the work." (I - Uruguay)

"Some consignees recognize their role as middle-men with the small producers." (C - Uruguay)

"There's not always an invitation. Some cooperate, others don't." (C - Brazil)

"You see a more competitive relationship in the short term between participants, and in the medium term (there's a perception) that one party doesn't exist without the other." (I-Argentina)

In the relationship between the headquarters and the units, we identified no major conflicts in the unit coordination process. These can occur when there is dissatisfaction between those involved, or when the parent company and subsidiary companies' objectives clash. According to the company this would not occur and there is, therefore, a situation of cooperation with little conflict, as can be identified from the comments. However, we are able to identify a level of potential producer dissatisfaction with the company with regard to unequal treatment because of the size of the producer; the Argentinian unit was the exception to this:

"The company makes contact and fetches them (the cattle) when they need to." (P - Brazil)

"Only about ten producers are involved in the chain planning activities." (P - Uruguay)

"We help and support each other. And we also have the necessary support from the industry." (P - Argentina)

\section{Relationshits in the Supply Chain}

\subsection{The UNIT IN URUGUAY}

The subsidiary in Uruguay has a degree of autonomy, but follows the goals planned by the headquarters. In line with this orientation, the unit seeks to organize and cooperate when new demands exist, and to maintain its routine activities in the market. The maintenance of the required international quality standards leads to the need of working together, especially with producers; thereby, creating conditions for raw material to arrive in accordance with the requirements that exist.

"The company arranges technical talks with producers. The aim is also to encourage communication between them." (I - Uruguay) 
BBR

15,6

With this objective in mind, there are collaborative relationships that benefit both parties. The development of these types of relationship, however, is difficult and aggravated due to the company's headquarters being outside Uruguay. Thus, there are areas for improvement in relationships within the chain. The existing gaps are similar to those found in the studies by Dyer and Chu (2000 and 2011), which state that supplier/buyer relationships should go beyond contracts and involve loyalty.

"Communication does not reach all producers ... there is a lack of information about the sector.”(P1 - Uruguay)

"The company doesn't pass on information that allows the producer to make new investments." (P2 - Uruguay)

This information differs from some previous studies, according to which time has a positive influence on the bonds of trust. In the case of the relationships studied here, the years of working together did not always lead to greater closeness. This period also created a distancing and led to a breakdown in relationships, as in the case of some of the consignees with the company. They were discouraged as they did not identify positive changes for themselves and moved away from both the activity and their trade partners.

"The industry draws together some of the consignees. (But) there's a lot of competition between them and many have already closed down ..." (C - Uruguay)

According to Sohn (1994), knowledge can be the basis for trust in long-term relationships, drawing the production and intermediary links closer together to work in a more collaborative and integrating way. However, given this knowledge is not passed on, since information about the market is centralized in the company, what we perceived was a certain level of aversion on the part of those involved in the chain to developing activities for a company that has great bargaining power.

We found that even with a traceability and certification system operating in the chain (this is a legal requirement in Uruguay), it is clear that many producers are not satisfied with the way of working. While this also includes processes, it has mainly to do with the relationships and policies adopted along the chain. At various times, the expressions "there's no cooperation" and "there's no chain" were noticeably emphasized, providing evidence that action needs to be taken in favor of quality in these relations.

"The industry has no sales or production plan with suppliers." (I - Uruguay)

"There's no organization in procurement." (P - Uruguay)

We can say, therefore, that the company unit located in Uruguay focuses on its relationship with large producers and large consignees, and that there is a gap when it comes to small and medium-sized producers and consignees. The need to expand management and coordination processes at the chain level was also mentioned by all the links participating in this study.

"Small and medium-sized producers are not always involved (in technical talks)." (P1 - Uruguay)

“(Face-to-face meetings) ... are not for everyone.” (P2 - Uruguay) 


\subsection{THE UNIT IN BRAZIL}

The parent company exercises much greater control over its unit in Brazil. We identified a gap in trust between the parties, but local players downplayed this aspect. There was still space in the Brazilian unit for developing actions with the other players that interact with the chain (suppliers, consumers, the labor market and the regional political system), in order to show the potential of the company and strengthen the role of each one in the chain. As the company had taken over a local company, an effort was needed to reduce the negative perception that the former had set up in the region with the objective of being a "large exploratory business". From this viewpoint, therefore, it lacked the social and structural trust of the population and of some of the suppliers and employees (GRANOVETTER, 1985; MACDUFFIE, 2011; and HANDFIELD \& BECHTEL, 2002).

We find social trust when we analyze the P-I relationship in individual local players. This type of trust, then, was stronger than the structural trust.

"Mr. L. G. does everything around here. He's a trustworthy guy. At first, the company was L .. Now it's changed." (C-Brazil)

"We trust the consignee. Without a contract. There's a packing list." (I - Brazil).

Activities in the chain are poorly coordinated by actions and contacts with the regional central office in another nearby municipality, and so there is no specific planning. This places a degree of pressure on the people who work in the company and who are in direct contact with producers and who need raw materials to be supplied in an agile manner.

There was a significant amount of involvement between consignees and company management (C-I). The former acted as intermediaries in the process between suppliers and the industry. The consignees thus help reduce direct contact between small suppliers and the company. There was also a reduction in logistical costs as a result of consolidating livestock loads. This is how barriers are created between the players that comprise the chain we analyzed.

"The industry does not pass on information that allows the producer to make new investments." (P - Brazil)

In the company's view, there was no progress in terms of cooperation. What existed was purely a buying and selling market relationship, in which producers will only be satisfied when they clearly perceive their gain. Cooperation was more obviously related to the activity of consignees that fetch the raw material from small producers and consolidate this raw material for the company. There was no competition in the supply, because since raw material was scarce, all deliveries and quantities were important to the company. Even with lower quality standards, when demand was high and accelerated by the regional central office, the search was constant and, at certain times of the year, the industry faced supply shortages.

When questioned about what it had learned from these relationships, the company responded that by getting closer to producers an effort was being made to qualify the producers by way of a program called Animal Welfare, and with regard to the industrial process, when there was an opportunity to monitor the slaughter of the loads being delivered by the producer.

The limited qualifications of many producers (most of them small and medium-sized, delivering in small batches) has been identified by the company as a problem when it comes to obtaining the new certifications demanded by the industry. Throughout the certification 
BBR

15,6

561

process, audits may take place that include interviews with producers to check their adoption of good practices.

\subsection{The Unit In Argentina}

The Argentinian unit cooperates with the parent company and its production processes and seeks to meet its demands and quality and standardization requirements. It discloses its processes to the company's headquarters and to other units. According to the company, there is trust in the relationship between this unit and the headquarters. Even with some changes, we can say that the parent company values the tradition and strengths of the Argentinian unit in both the local and international market. The Argentinian unit has invested significantly in its social environment and promoted its brand among various stakeholders over and above its direct chain (MENTZER ET AL., 2001), such as the consuming public, schools, events and technical institutions. Therefore, we seek a vision of the future that would work with the various relationships to provide continuity in delivery and maintenance of the quality of its products.

Constant activities were developed between the unit and its suppliers for technically qualifying the latter. The producers assessed different forms of communication with producers as being excellent. There was more information and greater knowledge, with opportunities for discussion and the consequent growth of those involved (producers and consignees).

In this unit in the post-acquisition period, despite the new way in which decision-making was organized, which included a Brazilian manager, there was still a need to deepen social ties. As the period when the acquisition took place was recent at the time of the research, the parent company and local community needed to accept the changes and recognize them. The unit was prominent regionally and intended to continue being so. Trust in the relationship between the Argentinian unit and the Brazilian headquarters was growing, but there was a continued need for attention to value the implicit knowledge, processes, tradition and the people.

There was involvement with other industrial units in horizontal relationships, but this was still incipient, as it only occurred in meetings promoted by the headquarters. However, we identified no clear policies that aimed to increase the involvement of this unit with the company's other industrial units. Involvement with the headquarters, on the other hand, was constantly being developed.

In analyzing the P-I relationship, we found that the industry was looking to increase the involvement of producers, as shown by the importance given to the various programs being developed. The explanation for the search for valuing producers was found in the unit's objectives and mission and in the way it maintained and developed existing relationships. Constant communication with producers was identifiable, as were programs aimed at bringing together and stimulating producers' opinions and suggestions. There were also technical lectures, aimed at improving producers' knowledge.

"We have various programs by which we try and involve suppliers and get closer to them." (I-Argentina)

From the point of view of the producer, these programs were considered important and would benefit the quality of the activities and draw this link closer to the industry. They emphasized the trust that already existed in the relationship between industry and producers, as they jointly faced up to the challenges posed by the state of affairs in Argentina, thus confirming some of the aspects that facilitate cooperation. 
"There is approach and involvement through various programs with producers, advice, personal contacts ..." (P-Argentina)

However, there were still gaps in coordination along the chain. This was not an integrated model that would allow production to be adjusted according to demand, just as it had not been in the other units that were studied. This always introduced a margin of insecurity and this was perhaps the main motivation behind the relationship (and attempt at loyalty-building) programs with suppliers.

"It's understood as a chain, but not as an organization that deals with chain management" (I-Argentina)

"... it's not easy in the short term, but there are attempts to balance production in terms of quantity and quality. " (P-Argentina)

Trust in the relationship between industry and producer is designed mainly in the structural typology (MADHOK, 1995), since the strength of the company and the brand and explicit work done in the different programs the company terms as tools are present.

As far as the suppliers issue is concerned, horizontal relations (ZYLBERSZTAJN \& LAZZARINI, 2005) were the highlight in the case of Argentina. Producers realize the benefits of cooperating with each other, learning, sharing experiences and helping each other when necessary, and the need to do so. We understand this type of action as a way of maturing and qualifying producers and for them to become more committed to their activity and to the industry.

"We help and support each other. And we also have the necessary support from the industry." (P - Argentina)

\section{Cross Analysis of the Cases}

Cross-analysis of the three cases led to the construction of Table 3 . We consider the relationships classified as low in terms of their presence in the analysis categories, but that concurrently had a low or medium alignment of information in this research, to be relationship

Table 3. Cross-analysis of the relationships, with presence and alignment indicators per unit Analysis categories identified - Presence (P) and Alignment (A)

\begin{tabular}{|c|c|c|c|c|c|c|c|}
\hline \multicolumn{3}{|c|}{ Country / Unit/ Type of relationship } & \multicolumn{5}{|c|}{ H (High), M (Medium), L (Low) } \\
\hline & & & Trust & $\begin{array}{l}\text { Coopera- } \\
\text { tion }\end{array}$ & $\begin{array}{l}\text { Communi- } \\
\text { cation }\end{array}$ & $\begin{array}{c}\text { Involve- } \\
\text { ment }\end{array}$ & $\begin{array}{l}\text { Coordina- } \\
\text { tion }\end{array}$ \\
\hline Unit 1 & Brazil & C-I & HP, HA & LP, HA & LP, HA & LP, HA & LP, HA \\
\hline Unit 1 & Brazil & $\mathrm{P}-\mathrm{C}$ & MP, MA & MP, HA & LP, HA & LP, HA & LP, HA \\
\hline Unit 1 & Brazil & P-I & HP, MA & LP, MA & MP, LA & LP, MA & LP, HA \\
\hline Unit 2 & Uruguay & C-I & MP, HA & LP, HA & LP, HA & MP, HA & MP, MA \\
\hline Unit 2 & Uruguay & $\mathrm{P}-\mathrm{C}$ & MP, MA & LP, HA & LP, HA & LP, HA & LP, HA \\
\hline Unit 2 & Uruguay & P-I & MP, HA & MP, HA & MP, MA & MP, MA & MP, MA \\
\hline Unit 3 & Argentina & C-I & HP, HA & HP, HA & HP, HA & HP, HA & HP, HA \\
\hline Unit 3 & Argentina & P-C & HP, HA & HP, HA & HP, HA & HP, HA & MP, HA \\
\hline Unit 3 & Argentina & P-I & HP, HA & HP, HA & MP, HA & HP, HA & HP, HA \\
\hline
\end{tabular}


BBR

15,6

563

links that deserve greater attention, since they were not substantially developed, but at the same time, differences of opinion emerged between the links in the chain.

We found this situation in the Brazilian subsidiary in the elements of cooperation and involvement in the P-I (Producer / Industry) relationship. Attention should also be paid to indicators of low presence, even if there is high alignment, when both those involved in the link have the same perception of the non-existence or insufficiency of this aspect, especially in the Brazilian unit in terms of cooperation, communication, involvement and coordination.

As the focal company in this study is the industrial plant, we assume that all the analysis variables ought to be both positive and important to relationships and should therefore be present. We found several relationships in this categorization. In the unit in Brazil, in the C-I (Consignee / Industry) relationship, we found that the presence of four of the five categories were low, except for trust. The situation was the same for the coordination, involvement and communication categories in the Producer / Consignee (P-C) relationship. In the Producer / Industry (P-I) relationship, there was an identical incidence for the coordination category. In the Uruguayan unit, this situation occurred in the Consignee / Industry (C-I) relationship with the cooperation and communication categories, and in the Producer / Consignee (P-C) relationship with the cooperation, coordination, communication and involvement indicators. The Argentinian unit had no low presence and high alignment levels in this study for any of the categories studied.

Cooperation is the indicator that, in a general analysis, is most often cited as having a low presence. This point requires greater attention, therefore, in chain relationships, especially in the Brazilian and Uruguayan units. On the other hand, from looking at the types of relationship and their deficiencies, we found that the C-I (Consignee / Industry) type was a link that requires the company and its headquarters' attention because it has low presence indicators in the criteria studied. From analyzing the data we collected, it is clear that the consignee is a link that often feels it is not included in the supply chain, and may indeed be excluded in the near future if industry and producers start negotiating directly.

The unit in Argentina is the subsidiary that had the greatest homogeneity in terms of the presence of analysis criteria and greater information alignment in the comparisons of the relationships formed with producers and the industry. This conclusion points to the fact that there are more effective relationships in the supply chain in this unit. The trust, cooperation, communication, involvement and coordination indicators are largely present and are perceived by the links that were studied. Actions performed at chain level can serve as an example for others at the multinational's units, provided they follow similar strategies.

We must stress that at the time of the research the company was using a low cost strategy for the Brazilian unit. The lower levels of financial investment and management effort might have been leading to lower levels of cooperation, whereas the units in Argentina, with their focus on greater added value, develop strategies that allow for greater cooperation. An emerging question is what results would be achieved if the strategies adopted were similar in all units.

We present a summary of the analytical codes we identified in this study (Figure 1) below, showing them placed in the presence and alignment quadrants by analysis category and unit studied. We can observe that the positioning in the low presence (LP) and high alignment (HA) indicators appear more evidently, which shows that the company should pay attention to these particular categories in their future actions. In the opinion of the interviewees, there was a need to increase actions that stimulated and promoted trust, cooperation, involvement, coordination and communication in accordance with the strategic objectives of the parent company.

The Argentinian unit stands out because of its ability to develop relationships with those characteristics that were studied and considered important for working in a supply chain, 
Figure 1. Position of the presence and alignment analytical codes by unit and type of relationship

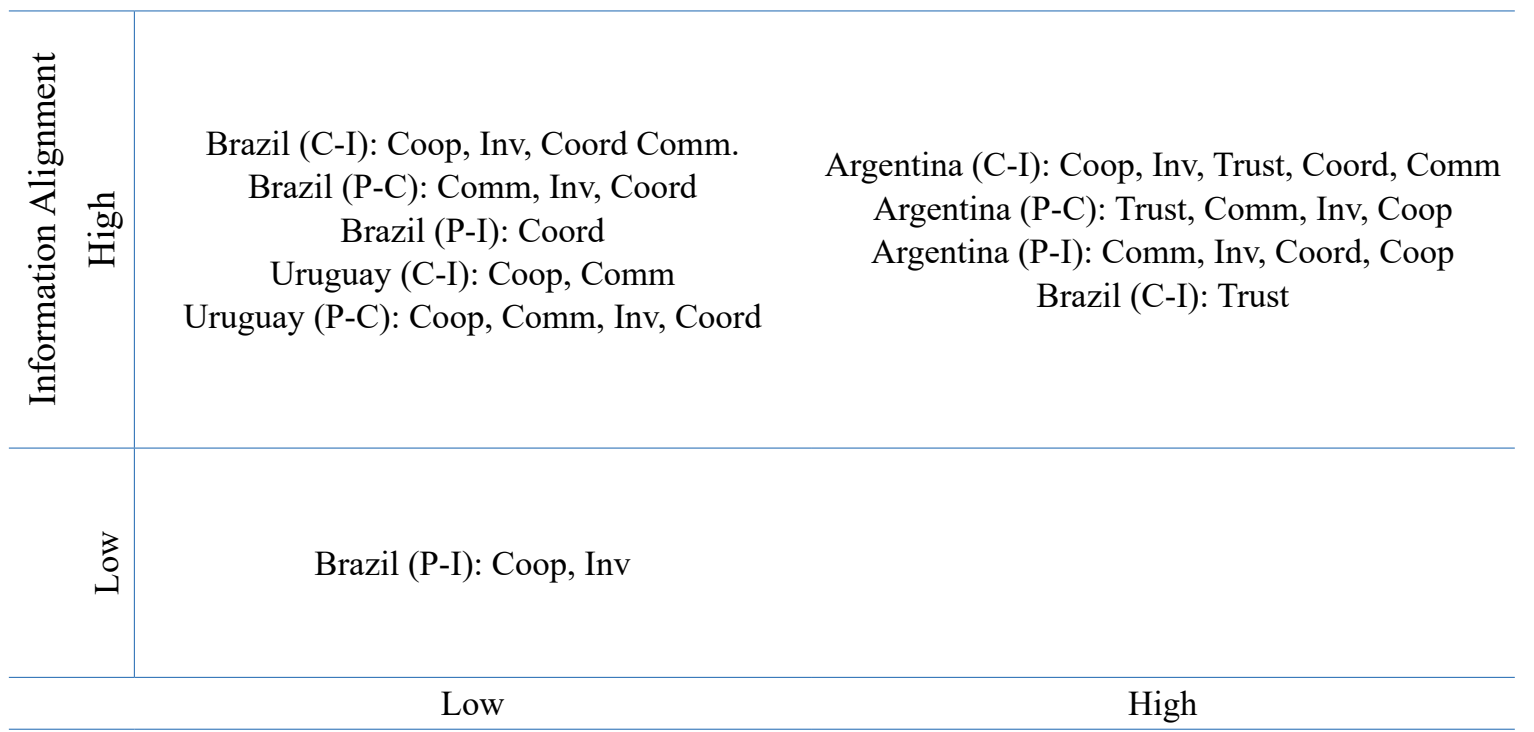

Source: Authors' own elaboration

positioning itself in the quadrant with high presence (HP) and high alignment (HA), indicators of information among those involved. We did not identify analysis categories in the low alignment (LA) and high presence (HP) positions, which would indicate that the perceptions and the actions actually implemented do not coincide.

\section{Conclusions}

In analyzing a multinational company that expanded its international activities through the acquisition of processing units in Brazil, Argentina and Uruguay, this study enables considerations to be made about the developments that arise from the acquisition of industrial operations. In this case, the supply chains were already formed before the acquisition of the units we studied. The challenge of the company has been to manage existing relationships effectively, while seeking a certain standardization in practices, but maintaining some of the specifics that serve the local context.

One aspect to highlight is that both the external environment and the strategies adopted affected the types of relationship in the chains that we investigated. In developing different business strategies in each unit, the company enables some preliminary statements to be made. The cases we analyzed suggest that in units with business strategies that seek greater differentiation or the creation of added value, especially the Argentinian unit, there is more collaboration and cooperation between the pairs that were analyzed. At the other extreme is the Brazilian unit. In this case, there is a low level of trust, which is reflected in its incipient cooperation and collaboration. This unit has policies that are clearly driven by a low-cost strategy.

We consider those relationships whose presence in the analysis categories and with or medium alignment of information is low (Table 3 ) to be links in the relationship that deserve more attention by the company. In these relationships, we identified the presence of different opinions between the links in the chain. This was most clearly present in the Brazilian subsidiary, especially in aspects related to the cooperation and involvement elements in the P-I (Producer / Industry) relationship.

Cooperation is the characteristic that, in a general analysis, was most often cited as having a low presence; in other words, this aspect requires the company to pay greater attention to its management of relationships. The difference in treatment dispensed by the 
BBR

15,6

565

company to the producer related to the size of the latter, the flow of information along the chain, and the lack of motivation of some of the consignees with regard to the company are all aspects that compromise the development of collaborative activities. Clearly the Argentinian unit is different, with a perception by both the company and its suppliers that there is collaboration in the chain. However, there are aspects of trust in the relationships, in the Brazilian unit and in the two foreign units. The study found, however, that these characteristics are also attributed to the people involved and not just to the company and/ or its processes (affective trust). Moreover, this perception is unequal between the different players, including producers, the industry and consignees.

We did not identify any analysis categories in the low alignment and high presence position, which would indicate that the views and information provided by those involved do not coincide with the evidence we found. This situation may be considered favorable, because changes in these alignment and presence categories would require high investments in management skills with a long-term impact.

With the aim of improving the coordination of the activities developed via relationships in the supply chain, the results suggest that the company could increase learning by way of a horizontal relationship. We can accomplish this by drawing the units closer to one another, which would benefit the Brazilian unit, in particular.

The results of this study contribute by analyzing supply chains in different countries. Generally speaking, studies involving Brazilian multinational companies (or companies from emerging countries, according to Meyer, 2004) do not address supply chain management. The internationalization of companies from these countries is still recent and, therefore, the focus has been on those factors that motivate operations in other countries. This study contributes by comparing the supply chains of the same company established in three Latin American countries that have different cultural and institutional characteristics. The advance offered by this paper is that it proposes analysis categories that allow the configuration of the relationships that exist in three supply chains to be differentiated and this can be replicated in other sectors and contexts. We can also use these categories as a guide for multinational managers when they are developing and managing international supply chains.

This study has its limitations, among which is the number of participants interviewed. A greater number of interviewees could lead to more in-depth and more valid results with regard to the relationships we analyzed. Another limitation has to do with the understanding of the concept of "cooperation". This aspect may mean that, based on perception and past experiences, those taking part in the research have different opinions with regard to the existence, or otherwise, of cooperative activities. Future research can explore these limitations, especially with survey-type studies, or by using secondary data taken from Brazilian multinational companies

\section{REFERENCES}

ARBIX, G., CASEIRO, L. Destination and strategy of Brazilian multinationals. Economics, Management and Financial Markets, v. 6, n. 1, p. 195-207, 2011.

ARIÑO, A. Measures of strategic alliance performance: an analysis of construct validity. Journal of International Business Studies, v. 34, n. 1, p. 66-79, 2003.

BARRATT, M., CHOI T.Y., LI, M. Qualitative case studies in operations management: Trends, research outcomes, and future research implications. Journal of Operations Management, v. 29, n. 4, p. 329-342, 2011.

BORINI, F. M., et al. The reverse transfer of innovation of foreign subsidiaries of Brazilian multinationals. European Management Journal, v. 30, n. 3, p. 219-231, 2012.

BORINI, F., FLEURY, M.T. Development of non-local competences in foreign subsidiaries of Brazilian multinationals. European Business Review, v.23, v.1, p. 106-119, 2011. 
BURGESS, K., SINGH, P. J. KOROGLU, R. Supply chain management: a structured literature review and implications for future research. International Journal of Operations and Production Management, v. 26, n. 7, p. 703-729, 2006.

CANTWELL, J., DUNNING, J. H., LUNDAN, S. M. An evolutionary approach to understanding international business activity: The co-evolution of MNEs and the institutional environment. Journal of International Business Studies, v. 41, p. 567-586, 2010.

CAPÓ-VICEDO, J., MULA, J.; CAPÓ, J. A social network-based organizational model for improving knowledge management in supply chains. Supply Chain Management: An International Journal, v. 16, n. 5, p. 379-388, 2011.

CHEN, I. J., PAULRAJ, A. Towards a theory of supply chain management: the constructs and measurements. Journal of Operations Management, v. 22, p. 119-150, 2004.

CRILLY, D. Predicting stakeholder orientation in the multinational enterprise: a mid-range theory. Journal of International Business Studies, v. 42, p. 694-717, 2011.

DYER, J., CHU, W. The determinants of trust in supplier-automaker relations in the US, Japan and Korea: A retrospective. Journal of International Business Studies, v. 42, p. 28-34, 2011.

FANG, E., \& ZOU, S. The effects of absorptive and joint learning on the instability of international joint ventures in emerging economies. Journal of International Business Studies, v. 41, n. 5, p. 906-924, 2010.

FLEURY, A., FLEURY, M.T. Brazilian multinationals: competences for internationalization. Cambridge University Press, 2011.

ZAHRA, S.A., IRELAND, R.D., HITT, M.A., International Market Entry Mode Decisions on Firm Global Performance: A Governance Perspective. Special Issue on Designing Competitive Strategies for Global Marketing, Research in Marketing, v. 14, p. 45-86.

GRANOVETTER, M. The impact of social structure on economic outcomes. Journal of Economic Perspectives, v.19, n. 1, p. 33-50, 2005.

HANDFIELD, R. B., BECHTEL, C. The role of trust and relationship structure in improving supply chain responsiveness. Industrial Maketing Management, v. 31, p. 367-382, 2002.

HENNART, J. K., PARK, Y. R. Greenfield vs. Acquisition: The Strategy of Japanese Investors in the United States. Management Science, v. 39, n. 9, p. 1054-1070, 1993.

HOFSTEDE, G., BOND, M. H. The Confucius connection: From cultural roots to economic growth. Organizational Dynamics, v.16, n. 4, p. 5-21, 1988.

HOULIHAN, J. B., International supply chain management. International Journal of Physical Distribution \& Materials Management, v. 15, n. 1, p. 22-38, 1985.

HUANG, M. C., YEN, G. F. \& LIU, T. C. Reexamining supply chain integration and the supplier's performance relationships under uncertainty. Supply Chain Management: An International Journal, v. 19, n. 1, p. 64-78, 2014.

JUTTNER, U., GODSELL, J., CHRISTOPHER, M. G. Demand chain alignment competence delivering value through product life cycle management. Industrial Marketing Management, v. 35, p. 989-1001, 2006.

KLASSEN, R., WHYBARK, D. Barriers to Management of International Operations. Journal of Operations Management, v. 11, p. 385-396, 1994.

KPMG. Ranking das Transnacionais Brasileiras 2010. Fundação Dom Cabral. Disponível em http://www. kpmg.com.br, 2010, Acesso em 10102012.

LINDGREEN, A. Trust as a valuable strategic variable in the food industry: different types of trust and their implementation, British Food Journal, v. 105, n. 6, p. 310-27, 2003.

LUO, Y., PARK, S. H. Multiparty cooperation and performance in international equity joint ventures. Journal of International Business Studies, v. 35, n. 2, p. 142-160, 2004.

MACDUFFIE, J. P. Inter-organizational trust and the dynamics of distrust. Journal of International Business Studies, v. 42, n. 1, p. 35-47, 2011.

MADHOK, A. Revisiting multinational firms' tolerance for joint ventures: A trust-based approach. Journal of International Business Studies, v. 26, p. 117-137, 1995.

MCALLISTER, D. J. Affect- and Cognition-Based Trust As Foundations for Interpersonal Cooperation in Organizations. Academy of Management Journal, v. 38, n. 1, 24-59, 1995.

MENTZER, J. T., DEWITT, W., KEEBLER, J. S., MIN, S., NIX, N. W., SMITH, C. D., ZACHARIA, Z. G. Defining supply chain management. Journal of Business logistics, v. 22, n. 2, p.1-25, 2001.

MEYER, K. E. Perspectives on multinational enterprises in emerging economies. Journal of International Business, v. 35, p. 259-276, 2004.

MEYER, K. E., ESTRIN, S. Brownfield entry in emerging markets. Journal of International Business Studies, v. 32, n. 3, p. 257-267, 2001. 
MISHLER, E. Research interviewing. Context and narrative. Cambridge: Harvard University Press, 1986.s[ep?

PAIVA, E. L., CARVALHO, JR, J. M., FENSTERSEIFER, J. E. Estratégia de Produção e de Operações: Conceitos, melhores práticas, visão de futuro. 2. ed. Porto Alegre: Bookman, 2009.

PARK, S. H., UNGSON, G. R. Interfirm Rivalry and Managerial Complexity: a conceptual framework of alliance failure. Organization Science, v.12, n. 1, p. 37-45, 2001.

PEREZ-ALEMAN, P., SANDILANDS, M. Building value at the top and the bottom of the global supply chain: MNC-NGO partnerships. California Management Review, v. 51, n. 1, p. 24-49, 2008.

PRASAD, S., BABBAR, S. International Operations Management Research. Journal of Operations Management, v. 18, p. 209-247, 2000.

RIESSMAN, C. K. Narrative Analysis. University of Huddersfield, 2005.

SIMATUPANG, T.M., SRIDHARAN, R. The collaborative supply chain. International Journal of Logistics Management, v. 13, p. 15-30, 2002.

SINGH, P.J., POWER, D. The nature and effectiveness of collaboration between firms, their customers and suppliers: a supply chain perspective, Supply Chain Management: An International Journal, v.14, n. 3, p. $189-200,2009$.

USDA. United States Department of Agriculture. Livestock and Poultry: world markets and trade. Disponível em: http://www.usda.org. Acesso em 18032014.

VEREECKE, A., MUYLLE, S. Performance improvement through supply chain, collaboration in europe. International Journal of Operations Production Management, v. 26, p. 1176-1198, 2006.

VIEIRA, L.M., TRAILL, W.B. Trust and governance of global value chains: The case of a Brazilian beef processor. British Food Journal, v. 110, p. 460-473, 2008.

VOSS, C., TSIKRIKTSIS, N. FROHLICH, M. Case research in operations management. International Journal of Operations and Production Management. v. 22, n. 2, p. 195-219, 2002.

WEBSTER, L., MERTOVA, P. Using narrative inquiry as a research method: An introduction to using critical event narrative analysis in research on learning and teaching. Ed. Routledge, 2007.

WITT, M. A., LEWIN, A. Y. Outward foreign direct investment as escape response to home country institutional constraints. Journal of International Business Studies, v. 38, n. 4, p. 579-594, 2007.

WILDING, R., HUMPHRIES, A. S. Understanding collaborative supply chain relationships through the application of the Williamson organisational failure framework. International Journal of Physical Distribution \& Logistics Management, v.36, n.4, p. 309-329, 2006.

WU, F., CAVUSGIL, S. T. Organizational learning, commitment and joint value creation in interfirm relationships. Journal of Business Research, v.59, p. 81-89, 2005.

ZUCKER, L.G. Production of trust: institutional sources of economic structure, 1840-1920. Research in Organizational Behaviour, n. 8, p. 53-71, 1986.

ZYLBERSZTAJN, D. \& LAZZARINI, S.G. On the survival of contracts: assessing the stability of technology licensing agreements in the Brazilian seed industry. Journal of Economics and Business Organization, v. 5, p.103-120, 2005. 